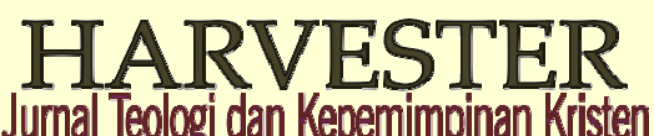

Available at: http://e-journal.sttharvestsemarang.ac.id/index.php/harvester

Volume 5,No2, Desember 2020;(86-104)

e-ISSN2685-0834,p-ISSN2302-9498

\title{
Pentingnya Peran Media Sosial dalam Pelaksanaan Misi di Masa Pandemi Covid-19
}

\author{
Yonatan Alex Arifianto \\ Sekolah Tinggi Teologi Sangkakala, Salatiga \\ e-mail: arifianto.alex@sttsangkakala.ac.id \\ Sari Saptorini \\ Sekolah Tinggi Teologi Baptis, Semarang \\ e-mail: sarisaptorini@stbi.ac.id \\ Kalis Stevanus \\ Sekolah Tinggi Teologi Tawangmangu \\ e-mail: kalisstevanus91@qmail.com
}

\begin{abstract}
The Coronavirus Disease 2019 (Covid-19) outbreak, or better known as the Corona virus, is spreading rapidly, bringing changes in socializing and communicating in the community. Government regulations require all citizens to participate in breaking the chain of transmission of the virus. This of course also has an impact on the concept and implementation of the mission that has been carried out, namely face to face. As one way the church must continue to take its role in witnessing or preaching the gospel of Jesus Christ to non-believers using social media as the right choice in carrying out missions during the Covid-19 pandemic. Through a qualitative descriptive approach, this article will describe the understanding of the Church or believers as recipients of God's mission mandate, and the use of social media as a means of carrying out missions during the Covid-19 pandemic, and how the effectiveness and constraints of carrying out missions through social media. Based on the results of this study, the mission is still carried out in all conditions in the midst of society even though without having to meet face to face with the church empowering its people to actively use social media as a means of preaching the gospel. Because all activities are currently being carried out online which can be a great opportunity to enter social media and creative learning as the implementation of missions in the midst of a pandemic.
\end{abstract}

Keywords: Church; Covid-19 Pandemic; Mission; Social Media.

Abstrak: Wabah Coronavirus Disease 2019 (Covid-19) atau lebih dikenal dengan nama virus Corona yang menyebar dengan cepat membawa perubahan dalam bersosialisasi dan berkomunikasi di masyarakat. Aturan pemerintah mengharuskan semua warga berpartisipasi 
dalam memutus rantai penularan virus tersebut. Hal itu tentu juga berdampak pada konsep dan pelaksanaan misi yang selama ini dilakukan, yakni dengan tatap muka secara langsung. Sebagai salah satu caranya gereja harus tetap mengambil perannya untuk bersaksi atau memberitakan Injil Yesus Kristus kepada orang-orang yang belum percaya menggunakan media sosial sebagai pilihan yang tepat di dalamnya pelaksanaan misi di masa pandemi Covid-19. Melalui pendekatan kualitatif deskriptif, artikel ini akan memaparkan pemahaman tentang Gereja atau orang percaya sebagai penerima mandat misi Allah, dan pemanfaatan media sosial sebagai salah satu sarana pelaksanaan misi di masa pandemi Covid-19, dan bagaimana efektivitas serta kendala pelaksanaan misi melalui media sosial. Berdasarkan hasil penelitian ini, maka misi tetap dilakukan dalam segala kodisi di tengah-tengah masyarakat meskipun tanpa harus tatap muka secara langsung dengan cara gereja memberdayakan umatnya untuk secara aktif menggunakan media sosial sebagai sarana pemberitaan Injil. Sebab seluruh kegiatan saat ini dilakukan menggunakan daring yang dapat menjadi peluang yang besar untuk masuk dalam media sosial dan pembelajaran yang berkreatif sebagai pelaksanaan misi di tengah pandemi.

Kata Kunci: Gereja; Misi; Media Social; Pandemi Covid-19.

\section{PENDAHULUAN}

Virus Coronavirus Disease 2019 (Covid-19) yang hadir di tengah-tengah masyarakat pada tahun 2020 pertama kali ditemukan di kota Wuhan, China sungguh menyita perhatian dunia. Dalam bidang medis, virus tersebut diberitakan dan disebarluaskan kepada masyarakat sebagai penyakit baru yang menyerang manusia dan beberapa hewan yang belum pernah teridentifikasi sebelumnya. Adapun dampak dari penyebaran virus tersebut tidak hanya memengaruhi kesehatan masyarakat, akan tetapi turut menggoncang perekonomian negara. Bahkan, saat ini perekonomian dunia pun mengalami tekanan berat akibat dari virus tersebut. ${ }^{1}$ Wabah Covid-19 tidak hanya merupakan masalah nasional dalam suatu negara, tapi sudah merupakan masalah dan persoalan global. ${ }^{2}$ Hampir seluruh negara di dunia saat ini menghadapi dan melawan persoalan bencana global kesehatan yang disebabkan oleh virus Corona. Situasi dan kondisi yang menakutkan oleh penyakit ini sangat memukul dunia serta seluruh penduduknya sehingga menyebabkan kekuatiran dan kegelisahan bahkan kekacauan yang dapat membuat orang putus asa dalam menjalani kehidupan. Kegelisahan dan

\footnotetext{
${ }^{1}$ Chairul Baharudin, Iksan and Muhammad Abdi, Nur, “Ancaman Krisis Ekonomi Global Dari Dampak Penyebaran Virus Corona (Covid-19)," AkMen Jurnal Ilmiah, 2020.

${ }^{2}$ Syafrida Syafrida, "Bersama Melawan Virus Covid 19 Di Indonesia," SALAM: Jurnal Sosial Dan Budaya Syar-I 7, no. 6 (2020), https://doi.org/10.15408/sjsbs.v7i6.15325.
} 
kekuatiran itu muncul karena tidak adanya kejelasan terhadap obat atau vaksin untuk virus tersebut dan secara kerohanian, tidak adanya kepastian pengharapan akan kehidupan setelah kematian.

Kekristenan ada untuk menjadi berkat dan kesaksian bagi dunia seperti yang dinyatakan Yesus bahwa orang percaya adalah garam dan terang dunia (Mat. 5:13-16). Sehingga apapun persoalan yang dihadapi orang percaya tetap mampu menjadi berkat karena di balik pengajaran yang dilakukan oleh orang percaya mendatangkan kebahagiaan. Seperti yang ditulis oleh Lukas Tetapi Ia berkata:"Yang berbahagia ialah mereka yang mendengarkan firman Allah dan yang memeliharanya (Lukas 11: 28), dengan hal ini maka orang-orang percaya bisa memiliki damai sejahtera Kristus sekalipun berada dalam situasi sulit oleh adanya pandemi virus Corona. Oleh karena itu, pandemi Virus Corona tidak seharusnya dipandang sebagai penghalang, melainkan sebagai peluang untuk melaksanakan misi Allah untuk menyelamatkan mereka yang terhilang. Stevanus menyatakan bahwa misi Amanat Agung dalam pelaksanaannya harus memerhatikan situasi sosial di tengah

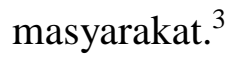

Sama halnya dengan Pendidikan yang harus memerhatikan budaya ${ }^{4}$, pemberitaan Injil tanpa memperhatikan konteks penerimanya, seperti budaya, suku, keadaan ekonomi, dan sebagainya sering menemui pelbagai kesulitan bahkan kegagalan. Dengan kata lain, strategi pekabaran Injil akan selalu berubah sesuai dengan kebutuhan zamannya. Itu sebabnya Injil harus diimplementasikan sesuai konteks kekinian karena Injil bukan sekadar diberitakan tapi untuk dipahami dan diterima sehingga banyak orang diselamatkan di dalam Kristus. ${ }^{5}$ Tentunya hal ini berlaku di tengah-tengah kondisi dan situasi masalah pandemi covid-19.

Gereja memperoleh mandat dari Tuhan Yesus Kristus untuk melaksanakan Amanat Agung-Nya dalam Matius 28:19-20: “Karena itu pergilah, jadikanlah semua bangsa murid-

\footnotetext{
${ }^{3}$ Kalis Stevanus, "Mengimplementasikan Pelayanan Yesus Dalam Konteks Misi Masa Kini Menurut Injil Sinoptik," FIDEI: Jurnal Teologi Sistematika Dan Praktika, 2018, https://doi.org/10.34081/fidei.v1i2.21.

${ }^{4}$ Frets Keriapy, "Pendidikan Kristiani Transformatif Berbasis Multikultural Dalam Konteks Indonesia," REGULA FIDEI: Jurnal Pendidikan Agama Kristen 5, no. 2 (2020): 82-93.

${ }^{5}$ Kalis Stevanus, "“Mengimplementasikan Pelayanan Yesus Dalam Konteks Misi Masa Kini Menurut Injil Sinoptik"," Fidei: Jurnal Teologi Sistematika Dan Praktika Vol.1, no. No.2 (2018): 285.
} 
$\mathrm{Ku}$ dan baptislah mereka dalam nama Bapa dan Anak dan Roh Kudus, dan ajarlah mereka melakukan segala sesuatu yang telah Kuperintahkan kepadamu. Dan ketahuilah, Aku menyertai kamu senantiasa sampai kepada akhir zaman." Selain itu, Tuhan Yesus juga berkata dalam Matius 24:14 bahwa Injil Kerajaan yang dibawa Yesus harus disaksikan kepada segala bangsa sebelum tiba kesudahan alam. Seluruh dunia akan mendengar Injil sebelum Tuhan Yesus datang kembali. Inilah dasar bagi orang percaya untuk terlibat di dalam pelaksanaan misi Allah. Injil memberikan pengharapan akan kesembuhan, pemeliharan, dan pertolongan Tuhan, terlebih keselamatan kekal sebagai kabar utama yang harus disampaikan kepada semua orang. Orang percaya harus memastikan dirinya terlibat dalam misi pemberitaan kabar baik dan sukacita atas keselamatan besar dari Allah bagi umat manusia. Sebagaimana dikemukakan Stevanus bahwa gereja adalah penerima mandat misi untuk merealisasikan Amanat Agung Kristus yaitu memberitakan Injil sampai ke ujung-ujung bumi. $^{6}$

Dengan adanya pandemi virus Corona, pemerintah melalui maklumat Kapolri menerbitkan larangan perkumpulan dan pembatasan interaksi sosial sebagai bentuk pencegahan penularan virus tersebut. Pemerintah juga mewajibkan masyarakat mematuhi rangkaian protokol kesehatan, termasuk menjaga jarak pada saat berkomunikasi secara langsung. Meski demikian, pembatasan interaksi bukan berarti pembatasan dalam pelaksanaan misi oleh gereja. Gereja masih tetap dapat melaksanakan misinya dengan memanfaatkan teknologi dan media sosial dalam jaringan internet sebagai sarana misinya. Hal itu dikarenakan adanya perkembangan teknologi informasi, internet dan media sosial yang kian mengubah bentuk pergaulan dan cara bersosialisasi masyarakat. ${ }^{7}$ Internet, gadget, dan media sosial bukan lagi menjadi hal yang baru bagi masyarakat dunia, maka pemberitaan Injil melalui media sosial pun juga sangat memungkinkan untuk dilaksanakan. ${ }^{8}$

Dari persoalan serius yang terjadi di masa pandemi sebagai latar belakang permasalahan, maka penulis meneliti dengan menggunakan kajian pustaka dengan

\footnotetext{
${ }^{6}$ Kalis Stevanus, "Karya Kristus Sebagai Dasar Penginjilan Di Dunia Non-Kristen,” Fidei: Jurnal Teologi Sistematika Dan Praktika Vol.3, no. No.1 (2020): 1-19.

${ }^{7}$ Anastasiaa Siwi Fatma Utami and Nur Baiti, "Pengaruh Media Sosial Terhadap Perilaku Cyberbullying Pada Kalangan Remaja," Cakrawala - Jurnal Humaniora, 2018.

${ }^{8}$ Kalis Stevanus, Penggilan Teragung: Pedoman Dan Metoda Praktis Untuk Memberitakan Kabar Baik Sampai Ke Ujung Bumi (Yogyakarta: Andi Offset, 2019),166 .
} 
mengusung tema Pentingnya Peran Media Sosial dalam Pelaksanaan Misi di Masa Pandemi Covid-19. Paper ini bertujuan untuk mengetahui bagaimana penggunaan media sosial yang sudah lumrah pada masa kini oleh orang percaya memegang peranan yang sangat penting bagi kemajuan pekerjaan misi Allah di tengah-tengah keterbatasan pada masa pandemi Covid-19. Era globalisasi yang maju dengan teknologi telah menyediakan peluang-peluang yang baik dengan segala kemudahan untuk pewartaan Injil. Maka hal itu menjadikan penginjilan melalui media sosial dapat menjadi pilihan yang tepat untuk menjangkau bagianbagian dunia yang tidak dapat dijangkau oleh media-media lain, ${ }^{9}$ terlebih dalam kondisi pandemi Covid-19.

\section{METODE PENELITIAN}

Untuk menjawab pertanyaan mengenai pentingnya peran media sosial dalam melaksanaan misi di masa pandemi Covid-19, penulis menggunakan penelitian kualitatif deskriptif. ${ }^{10}$ Dengan pendekatan studi pustaka penulis juga melakukan kajian dari berbagai sumber literatur berupa jurnal teologi ataupun buku-buku yang sesuai dengan tema, sehingga diperoleh gambaran pelaksanaan misi dalam penelitian ini, penulis juga memaparkan secara deskriptif dan sistematis sesuai kaidah penulisan. Selain menggunakan Alkitab sebagai referensi primer, juga dipergunakan buku-buku dan sumber-sumber sekunder lainnya yang relevan dengan topik sesuai prinsip literatur review yang dimaksud oleh Denney. ${ }^{11}$

\section{HASIL DAN PEMBAHASAN}

\section{Gereja Sebagai Penerima Mandat Misi Allah}

Pelaksanaan mandat misi merupakan tanggungjawab yang diembankan oleh Tuhan Yesus Kristus kepada seluruh orang Kristen. ${ }^{12}$ Misi adalah pertemuan antara orang percaya

\footnotetext{
9 Adrianus Pasasa, "Pemanfaatan Media Internet Sebagai Media Pemberitaan Injil,” Jurnal Simpson 2, no. 1 (2015): 71-98.

${ }^{10}$ Conny R Semiawan, Metode Penelitian Kualitatif (Jakarta: Grasindo, 2010), 108.

${ }^{11}$ Andrew S. Denney and Richard Tewksbury, "How to Write a Literature Review," Journal of Criminal Justice Education 24, no. 2 (2013): 218-34, https://doi.org/10.1080/10511253.2012.730617.

12 Seri Damarwanti, "Pandangan Rasul Paulus Tentang Jembatan Pengantar Injil. Kajian Misiologi Terhadap I Korintus 9:1-23,” SANCTUM DOMINE: JURNAL TEOLOGI, 2020, https://doi.org/10.46495/sdjt.v8i2.53.
} 
yang dipanggil keluar dari kegelapan dengan orang-orang yang jauh dari pengaruh Injil. ${ }^{13}$ Gereja seharusnya menyediakan diri untuk dituntun oleh Allah menjumpai mereka yang belum pernah mendengar tentang Injil Kristus. Gereja terdiri dari orang-orang percaya yang secara pribadi telah menerima anugerah keselamatan dari Allah. Orang percaya sudah sepatutnya berterima kasih dan bersyukur kepada Allah melalui ketaatannya kepada perintah Allah. Penginjilan adalah wujud cinta kasih orang percaya kepada Allah dan kepada sesama manusia dengan sepenuhnya untuk keselamatan manusia dan untuk memuliakan Tuhan karena diberi kesempatan menjadi kawan sekerja Tuhan. ${ }^{14}$ Penginjilan adalah pekerjaan pelayanan yang sangat mulia, sebab membawa setiap manusia atau orang yang belum mengenal kabar baik dari berita Sorga mengenali akan dosanya lalu percaya dan mengalami pertobatan dengan menerima Yesus sebagai Tuhan dan Juruselamat, dan percaya dengan sungguh bahwa di dalam Yesus ada keselamatan, pengharapan dan kepastian hidup yang kekal. ${ }^{15}$ Dengan demikian, Gereja seharusnya menerima mandat misi Allah dengan penuh sukacita dan ketaatan dalam melaksanakan penginjilan kepada orang-orang yang belum percaya. Karena sejatinya penginjilan adalah tugas semua orang percaya tanpa terkecuali. ${ }^{16}$

Gereja yang bertumbuh adalah gereja yang memusatkan tujuan utamanya terhadap Penginjilan. Sebab misi yang diberitakan juga menjadi prasyarat untuk pertumbuhan dan pengembangan gereja. ${ }^{17}$ Gereja mula-mula bertumbuh dengan pesat karena para rasul, murid-murid, dan semua orang yang percaya dari pemberitaan mereka menaati perintah Tuhan Yesus Kristus untuk menyebarluaskan berita Injil kepada semua orang yang mereka temui. George W. Peters menyatakan bahwa: gereja yang memiliki semangat yang kuat untuk memberitakan Injil Yesus Kristus adalah gereja yang memberitakan Injil sesuai dengan

${ }^{13}$ Edmund Woga, Dasar-Dasar Misiologi (Yogyakarta: penerbit Kanisius, 2002), 18.

${ }^{14}$ Stefany John Risna Abrahamsz and Petronella Tuhumury, "Model Penginjilan Dalam Yohanes 4:4-42 Dan Implementasinya Pada Masa Kini," Jurnal Jaffray 10, no. 2 (2012): 104-39, https://doi.org/10.25278/jj71.v10i2.55.

${ }^{15}$ Abrahamsz and Tuhumury.

${ }^{16}$ Yonatan Alex Arifianto, Reni Triposa, and Paulus Karaeng Lembongan, "Bible Study of Mission and Discipleship in the Great Commission and Its Implications for Today's Christian Life," Diegesis: Jurnal Teologi 5, no. 2 (2020): 25-42.

${ }^{17}$ Edmund Woga, Misi, Misiologi, Dan Evangelisasi Di Indonesia (Yogyakarta: penerbit Kanisius, 2009), 3. 
gereja mula-mula. ${ }^{18}$ Oleh karena itu, gereja masa kini yang ingin bertumbuh juga harus semangat dalam melaksanakan mandat misi Allah.

Kata "misi" itu sendiri berasal dari kata Latin missio adalah bentuk substantif dari kata kerja mittere (mitto, missi, missum) yang mempunyai pengertian dasar yang beragam, yaitu: membuang, menembak, membenturkan, mengutus, mengirim, membiarkan, membiarkan pergi, melepaskan pergi, membiarkan mengalir. Namun dalam konteks karya penyelamatan Allah bagi umat manusia, kata tersebut cenderung berarti mengutus. Pelaksanaan misi jelas merupakan mandat Allah yang tertulis di dalam Alkitab. Oleh karena itu, pemahaman mengenai landasan pekabaran Injil sangat penting dimasukkan dalam kegiatan pengajaran dan pembinaan gereja. ${ }^{19}$

Pengajaran dan pembinaan kepada jemaat mengenai misi Allah yang lengkap akan menolong setiap orang percaya untuk berpartisipasi aktif dalam pelaksanaannya.

Misi yang telah diperintahkan oleh Allah merupakan tugas dan tanggung jawab yang tidak dapat ditolak oleh semua orang percaya, karena sesuai dengan sifatnya, yakni sebuah amanat yang datangnya dari Allah sendiri. ${ }^{20}$ Maka, tugas Penginjilan adalah tugas semua orang percaya tanpa terkecuali. Hal itu dipertajam oleh Rasul Paulus dalam surat I Korintus 9:16 "Bahwa pemberitaan Injil adalah sebuah keharusan dan bukan pilihan". ${ }^{21}$ Meskipun tugas penginjilan adalah suatu keharusan, orang percaya tidak dapat melakukannya dengan kekuatannya sendiri. Orang percaya membutuhkan kekuatan kuasa Allah, yang dinyatakan melalui pekerjaan Roh Kudus (Lukas 24:49). ${ }^{22}$ Penggenapan misi Kristus hanya dapat terjadi ketika gereja bertindak dalam ketaatan oleh kekuatan dan kuasa Allah. ${ }^{23}$ Dengan tujuan

\footnotetext{
${ }^{18}$ George W. Peters, Teologi Pertumbuhan Gereja (Malang: Gandum Mas, 2013), 56.

${ }^{19}$ Markus Oci, "Implikasi Misiologi Dalam Pengembangan Kurikulum Agama Kristen Di Gereja Lokal,” FIDEI: Jurnal Teologi Sistematika Dan Praktika, 2019, https://doi.org/10.34081/fidei.v2i1.29.

${ }^{20}$ Handreas Hartono, "Mengaktualisasikan Amanat Agung Matius 28:19-20 Dalam Konteks Era Digital," Kurios 4, no. 2 (2018): 157-166.

${ }^{21}$ Kejar Hidup Laia, "Pertumbuhan Gereja Dan Penginjilan Di Kepulauan Nias," FIDEI: Jurnal Teologi Sistematika Dan Praktika, 2019, https://doi.org/10.34081/fidei.v2i2.46.

${ }^{22}$ Abrahamsz and Tuhumury, "Model Penginjilan Dalam Yohanes 4:4-42 Dan Implementasinya Pada Masa Kini."

${ }^{23}$ Dr. Yakob Tomatala, Penginjilan Masa Kini Jilid I (Malang: Gandum Mas, 2004).
} 
memberitakan Kristus yang mati bagi semua umat manusia dan menjadi Penebus sejati dunia. $^{24}$

Tuhan Yesus menyatakan di dalam Kisah Para Rasul 1:8, bahwa setiap orang percaya menerima kuasa ketika Roh Kudus turun ke atasnya dan menjadi saksi Kristus di Yerusalem, dan di seluruh Yudea dan Samaria dan sampai ke ujung bumi. Kata "kuasa" berasal dari kata dunamin, dari akar kata dunamis yang secara literal berarti, kuasa (power), keperkasaan (might), kekuatan (strength), daya (force) yang dapat ditemukan juga di dalam Matius 14:2; 22:29; Kis. 1:8; Rom. 1:4; Kol. 1:11; 2 Tim. 3:5; Ibr. 7:16; 2 Pet. 1:3. Secara sederhana, dunamis dapat diartikan suatu kekuatan, kuasa, kemampuan yang memungkinkan sesuatu untuk dilakukan atau diselesaikan. Dalam konteks ini, hal itu berarti bahwa dengan dunamis dari Roh Kudus para murid akan dimampukan dan diperlengkapi untuk bersaksi bagi Kristus. ${ }^{25}$ Kuasa Roh Kudus yang diterima oleh orang percaya bukan hanya akan memampukannya menyampaikan kesaksian tentang Injil, melainkan juga mengubahkan hidupnya sebagai saksi Kristus yang menjadi berkat bagi sesama. ${ }^{26}$ Perubahan hidup tersebut harus berpusat kepada Allah. ${ }^{27}$ Dan keinginan Yesus terhadap kehadiran Roh Kudus bagi manusia adalah agar dapat menuntun manusia untuk mengerti keadaan zaman demi zaman yang akan dilalui manusia supaya manusia menghidupi kebenaran Allah. ${ }^{28}$

Roh Kudus memberikan kuasa, menggerakkan dan mengarahkan Gereja-Nya untuk melaksanakan misi Allah sesuai dengan tujuannya. Sebagaimana diungkapkan Stevanus, sesuai sifatnya yang terkandung dalam perintah Amanat Agung, Injil adalah untuk semua orang. ${ }^{29}$ Tujuan dari misi seperti yang tercantum dalam Amanat Agung adalah untuk memuridkan segala bangsa. Dalam studi etimologi, kata "bangsa" dalam Bahasa Yunani adalah etnos yang memiliki arti merujuk kepada etnis atau suku. Dengan demikian, jelas

${ }^{24}$ Elkana Chrisna Wijaya, "Deskripsi Hamba Yang Menderita Menurut Yesaya 52:13-53:12,"

EPIGRAPHE: Jurnal Teologi Dan Pelayanan Kristiani, 2019, https://doi.org/10.33991/epigraphe.v2i2.38.

${ }^{25}$ Heryanto David Lie, "Penggenapan Progresif Misi Allah Dalam Kisah Para Rasul 1: 8 Progressive Fulfillment of God 's Mission in Act 1: 8," Jurnal Jaffray 15, no. 1 (2017).

${ }^{26}$ Abrahamsz and Tuhumury, "Model Penginjilan Dalam Yohanes 4:4-42 Dan Implementasinya Pada Masa Kini."

${ }^{27}$ J. Andrew Kirk, Apa Itu Misiologi? (Jakarta: BPK Gunung Mulia, 2015), 92.

${ }^{28}$ Yonatan Alex Arifianto and Asih sumiwi Rachmani, "Peran Roh Kudus Dalam Menuntun Orang Percaya Kepada Seluruh Kebenaran Berdasarkan Yohanes 16 : 13," Jurnal Diegesis 3, no. 1 (2020): 1-12.

${ }^{29}$ Kalis Stevanus, Benarkah Injil Untuk Semua Orang (Yogyakarta: Diandra Kreatif, 2019), 25. 
bahwa Tuhan Yesus menginginkan agar setiap suku, kaum dan bahasa, termasuk yang ada di Indonesia, menjadi murid-Nya dan memperoleh keselamatan.

Pekerjaan misi bukanlah pekerjaan yang mudah. Sejak masa lahirnya gereja mulamula, penginjilan sudah menghadapi berbagai macam tantangan dan rintangan baik dari dalam maupun dari luar. Rasul Paulus sendiri mengatakan bahwa dalam perjalanan misinya, berbagai macam bahaya mengintainya seperti bahaya banjir, bahaya penyamun, bahaya dari pihak orang-orang Yahudi, bahaya dari pihak orang-orang bukan Yahudi, bahaya di kota, bahaya di padang gurun, bahaya di tengah laut, dan bahaya dari pihak saudara-saudara palsu. Selain itu, ada kalanya ia juga harus mengalami penganiayaan dan penderitaan (2 Korintus 11:25-27). Demikian pula pada zaman sekarang, pekerjaan misi memiliki tantangan dan rintangannya sendiri. Namun tantangan demi tantangan itu tidak boleh melemahkan semangat memenangkan jiwa bagi Yesus Kristus. ${ }^{30}$

Pandemi Covid-19 hanyalah salah satu dari sekian banyak tantangan yang dihadapi gereja dalam pelaksanaan misi hari ini. Pemerintah sangat menganjurkan masyarakat untuk menaati aturan pembatasan kegiatan masyarakat dan penjagaan jarak supaya dapat memutus rantai penularan Covid-19. Gereja merupakan dari masyarakat dan bangsa Indonesia, maka gereja harus bersedia mendukung dan tunduk pada peraturan yang ditetapkan oleh pemerintah demi kemanusiaan. Sebagai akibatnya, gereja tidak dapat melakukan penginjilan secara langsung bertatap muka dengan targetnya. Bukan hanya itu, masyarakat pun jadi enggan meluangkan waktu berlama-lama untuk bergaul atau berkomunikasi dengan orang lain demi terhindar dari penularan Covid-19. Meski demikian, bukan berarti gereja beristirahat dari tugasnya untuk melaksanakan misi. Amanat Agung memaparkan tujuan utama sebagai prioritas untuk membawa jiwa bagi Tuhan. ${ }^{31}$ Pemberitaan Injil yang dilakukan sejak gerakan penginjilan Yesus Kristus hingga masa kini memiliki tujuan supaya setiap orang yang belum percaya dan belum mengenal Kristus dapat diselamatkan. ${ }^{32}$ Memang ada resiko yang harus dipertimbangkan oleh gereja apabila di masa pandemi sekarang ini masih melakukan pekerjaan misi secara langsung, yakni kemungkinan dibawa

${ }^{30}$ Hannas and Rinawaty, "Menerapkan Model Penginjilan Pada Masa Kini," Kurios 5, no. 2 (2019): 175-89.

${ }^{31}$ David J. Bosch, Tranformasi Misi Kristen (Jakarta: BPK Gunung Mulia, 1998).

${ }^{32}$ Dever Mark, Sembilan Tanda Gereja Yang Sehat (Surabaya: Momentum, 2010), 87-88. 
dalam ranah hukum yang berlaku akibat tidak mentaati pemerintah untuk memutus mata rantai Covid-19. Untuk itu, gereja harus menemukan suatu cara yang efektif dalam menyampaikan Injil Kristus di tengah pandemi Covid-19.

\section{Media Sosial Sebagai Salah Satu Sarana Misi di Masa Pandemi Covid-19}

Perkembangan teknologi informasi dan komunikasi secara bertahap semakin maju dan digunakan dalam berbagai sektor organisasi lainnya. ${ }^{33}$ Media sosial Era globalisasi ditandai dengan kemajuan teknologi, salah satunya adalah internet. Tidak dapat dipungkiri bahwa kehadiran internet semakin dibutuhkan oleh umat manusia, baik dalam bidang pendidikan, pekerjaan atau bisnis, kegiatan bersosialisasi, maupun dalam aktivitas seharihari lainnya. Demikian pula media sosial telah menjadi kebutuhan manusia saat ini. Tidak hanya untuk berinteraksi dengan orang-orang terdekat, media sosial bisa digunakan untuk berbagai macam keperluan, seperti: mencari teman lama yang terkoneksi dan juga dapat menambah teman baru, mencari pekerjaan, berjualan, berbagi momen penting, dan sekedar mencari hiburan. Media sosial merupakan salah satu media yang berkembang paling pesat. Sekitar 70\% dari pengguna internet di seluruh dunia juga aktif dalam media sosial.

Media sosial seperti Facebook, Twitter, Instagram, Youtube dan layanan pesan instan WhatsApp masih sangat tinggi tingkat penggunanya sampai saat ini. Meski demikian, penggunaan media sosial juga telah menyebabkan segudang masalah, antara lain pergeseran budaya dari budaya tradisional menjadi budaya digital. ${ }^{34}$ Cahyono menambahkan bahwa lahirnya media sosial menjadikan pola perilaku masyarakat mengalami pergeseran baik budaya, etika dan norma yang ada. ${ }^{35}$ Selain itu, penyalahgunaan media sosial dapat saja menghasilkan perilaku komunikasi sosial yang buruk. Tidak heran jika ada perilaku pengabaian orang lain dalam berinteraksi karena perhatian yang lebih tertuju kepada ponsel

${ }^{33}$ Dalam Mendukung and Pembelajaran Pendidikan, "Penggunaan Media Sosial Di Kampus Dalam Mendukung Pembelajaran Pendidikan," Jurnal Wacana XIV, no. 1 (2015): 45-70.

${ }^{34}$ Fahmi Anwar, "Perubahan Dan Permasalahan Media Sosial," Jurnal Muara Ilmu Sosial, Humaniora, Dan Seni, 2017, https://doi.org/10.24912/jmishumsen.v1i1.343.

35 Anang Sugeng Cahyono, "Pengaruh Media Sosial Terhadap Perubahan Sosial Masyarakat Di Indonesia,” Jurnal Publiciana, 2016, 140-57. 
(phubbing), perundungan (bullying) dan pencurian data untuk penipuan. ${ }^{36}$ Bahkan ujaran kebencian (hate speech) mengiringi kebebasan berpendapat di media sosial. ${ }^{37}$ Oleh karena itu, masyarakat seharusnya mewaspadai kebebasan berekspresi serta tetap berpegang pada etika komunikasi dan pengendalian diri yang baik. ${ }^{38}$

Kekuatan media sosial memengaruhi masyarakat didasarkan secara eksklusif pada aspek sosialnya. ${ }^{39}$ Hal itu dikarenakan media sosial adalah sebuah perangkat lunak untuk bersosialisasi satu sama lain dan dilakukan secara online yang memungkinkan manusia untuk saling berinteraksi tanpa dibatasi ruang dan waktu. ${ }^{40}$ Pengaruh media sosial sangat besar hingga dapat membuat seseorang yang awalnya tidak terkenal bisa menjadi besar dan terkenal, atau sebaliknya. ${ }^{41}$ Dalam setiap kegiatan interaksi, biasanya melibatkan komunikasi baik dilakukan secara verbal maupun non-verbal. Dengan adanya perangkat lunak canggih yang dihasilkan dari perkembangan teknologi, gaya komunikasi mengalami perubahan. Perubahan tersebut tampak dari banyaknya yang menggunakan media digital sebagai media komunikasi. Semula teknologi yang terkait dengan komunikasi adalah pemanfaatan telepon, telegram, dan radio sebagai media komunikasi. Akan tetapi, memasuki era revolusi industri 4.0, perkembangan media komunikasi menjadi semakin pesat. Gereja harus memanfaatkan perkembangan teknologi informasi komunikasi dan kekuatan pengaruh media sosial sebagai peluang dan sarana bagi pelaksanaan misi. ${ }^{42}$ Seorang komunikator Kristen harus dapat menggunakan media digital dan media sosial dengan baik. Penggunaan media tersebut tentunya harus memenuhi asas manfaat, efektif, dan efisien. Ketika semua asas tersebut dipenuhi, penjangkauan terhadap kelompok orang yang belum mengenal Kristus

${ }^{36}$ Ruat Diana, "Peran Komunikator Kristen Dalam Strategi Pekabaran Injil Di Era Revolusi Industri 4.0," Integritas: Jurnal Teologi, 2019.

${ }^{37}$ Vibriza Juliswara, "Mengembangkan Model Literasi Media Yang Berkebhinnekaan Dalam Menganalisis Informasi Berita Palsu (Hoax) Di Media Sosial," Jurnal Pemikiran Sosiologi, 2017, https://doi.org/10.22146/jps.v4i2.28586.

${ }^{38}$ Anwar, "Perubahan Dan Permasalahan Media Sosial."

${ }^{39}$ Berliani Ardha, "Social Media Sebagai Media Kampanye Partai Politik 2014 Di Indonesia," Visi Komunikasi, 2014.

${ }^{40}$ Rafi Saumi Rustian, “Apa Itu Sosial Media,” 01 Maret 2012, 2012.

${ }^{41}$ Wilga Secsio Ratsja Putri, Nunung Nurwati, and Meilanny Budiarti S., "Pengaruh Media Sosial Terhadap Perilaku Remaja," Prosiding Penelitian Dan Pengabdian Kepada Masyarakat 3, no. 1 (2016), https://doi.org/10.24198/jppm.v3i1.13625.

${ }^{42}$ Diana, "Peran Komunikator Kristen Dalam Strategi Pekabaran Injil Di Era Revolusi Industri 4.0." 
dimungkinkan dapat terjadi. ${ }^{43}$ Sebaliknya, bila media sosial disalahgunakan, maka akan menjadi candu yang membuat penggunanya ketagihan hingga tiada hari tanpa membuka media sosial, ${ }^{44}$ untuk hal-hal yang tidak pantas dan mempermalukan atau melukai orang lain lewat segala aktivitas yang dilakukan di dunia maya.

Para pemimpin gereja harus dengan setia mengajar jemaat supaya tetap waspada dengan penggunaan media sosial supaya jemaat tidak menjadi batu sandungan dalam bermain media sosial yang dapat mengakibatkan terhambatnya penginjilan melalui media sosial. Bukan hanya itu, pemimpin gereja hendaknya juga mengajar dan melatih jemaat untuk terlibat secara aktif dalam pelaksanaan misi dengan memanfaatkan media sosial. Walaupun media sosial tidak ditujukan untuk menggantikan media-media lain, tapi penginjilan melalui media sosial dalam jaringan internet dapat menjadi alternatif untuk menjangkau bagianbagian dunia yang tidak dapat dijangkau oleh media-media lain. Terlebih dengan adanya peraturan pemerintah dan maklumat Kapolri tentang menjaga jarak serta anjuran untuk mengerjakan segala sesuatu dari rumah termasuk bekerja dan belajar, masyarakat menjadi semakin terhubung dengan media sosial. Sebagai pilihan yang tepat dalam pelaksanaan dapat menjangkau, setiap lapisan umur dapat dijangkau dengan mudah melalui pelayanan media, terlebih dalam masa pandemi saat ini seluruh aktivitas dan belajar, bekerja dan segala melakukan aktivitas dibatasi dan menggunakan daring adalah solusinya.

Pemanfaatan media sosial sebagai alat penginjilan dapat dikategorikan sebagai penginjilan masal dan penginjilan pribadi. Sebagai penginjilan massal, karena melalui media sosial sebagai perangkat lunak dalam jaringan internet berita tentang Yesus Kristus dapat disampaikan kepada banyak orang dalam waktu yang bersamaan, tidak dibatasi usia, tidak dibatasi oleh dimensi ruang dan waktu, juga tidak dibatasi oleh batas-batas negara dengan segala birokrasinya. Jadi peluang untuk menyampaikan berita Injil sangat terbuka di sana, ${ }^{45}$ namun isi konten dalam misi tidak boleh mengandung unsur SARA. Sedangkan sebagai penginjilan pribadi, karena dapat dilakukan kepada perorangan, ${ }^{46}$ dengan kecanggihan smartphone dan aplikasi. Membangun sarana penginjilan dengan internet melalui media

\footnotetext{
${ }^{43}$ Diana.

${ }^{44}$ Putri, Nurwati, and S., "Pengaruh Media Sosial Terhadap Perilaku Remaja."

45 Pasasa, "Pemanfaatan Media Internet Sebagai Media Pemberitaan Injil."

46 Pasasa.
} 
sosial hampir dapat dilakukan oleh semua orang percaya dengan biaya yang murah dan jangkauan yang luas. Dengan demikian, tantangan yang timbul dari perkembangan era industri revolusi 4.0 dimana perilaku sosial manusia yang cenderung sibuk dalam media sosial dan minimnya interaksi langsung dapat diatasi. Perkembangan teknologi memungkinkan orang percaya dapat melakukan penginjilan dengan platform dan cara-cara yang baru, yang justru dapat menjangkau lebih banyak orang di seluruh penjuru dunia. Media sosial sesungguhnya dapat menjadi media yang efektif untuk membawa pesan Injil, dan semuanya dapat diakses oleh semua orang. ${ }^{47}$

Selain mengajar dan melatih jemaat untuk memanfaatkan media sosial sebagai sarana penginjilan, ada hal lain yang dapat dilakukan oleh gereja dalam pelaksanaan misi, antara lain menyediakan materi untuk isi (content) untuk disampaikan jemaat dalam media sosialnya. Ada kalanya jemaat tidak mengerti apa saja yang harus disampaikan di dalam penginjilan, bagaimana menjawab pertanyaan-pertanyaan yang muncul ketika memberitakan Injil, bagaimana menindaklanjuti orang-orang yang tertarik dengan Injil, bagaimana menanggapi orang-orang yang menyerang dengan ujaran kebencian dan lain sebagainya. Tentu pemimpin gereja harus menyiapkan supaya apabila hal-hal tersebut terjadi, jemaat sudah siap dan memiliki sifat pantang menyerah dalam menjalankan misinya. Gereja perlu melakukan inovasi sehingga dihasilkan strategi pekabaran Injil yang relevan. Apabila telah dihasilkan sebuah inovasi maka perlu peran aktif dan positif para orang percaya untuk membuat content misi di media sosial masing-masing. ${ }^{48}$ Ketika hal ini dilakukan para pemimpin gereja dan jemaat secara bersama-sama, bukan tidak mungkin sebuah gerakan penginjilan melalui media sosial yang masif terjadi di Indonesia.

\section{Efektivitas dan Kendala Pelaksanaan Misi Melalui Media Sosial}

Pesatnya kemajuan teknologi di zaman ini menjadikan sarana-sarana yang dipakai dalam penyampaian informasi dan komunikasi semakin canggih. Gereja sedang ditantang untuk memanfaatkan kemajuan teknologi tersebut dalam memenuhi mandat Amanat Agung

${ }^{47}$ Arozatulo Telaumbanua, "E-Misi : Aplikasi Penginjilan Berbasis Teknologi," in Prodising, vol. 0, 2020, 1-11.

${ }^{48}$ Diana, "Peran Komunikator Kristen Dalam Strategi Pekabaran Injil Di Era Revolusi Industri 4.0." 
Tuhan Yesus. Orang-orang Kristen tentunya harus mempersiapkan diri dan mau belajar supaya tidak ketinggalan zaman dan gagap teknologi demi menunjang efektifitas pelaksanaan misi melalui media sosial. Teknologi internet sudah pasti memberikan kemudahan berkomunikasi bagi umat manusia. ${ }^{49}$ Internet memberikan manusia suatu peluang untuk berkomunikasi dengan siapa saja, karena internet tidak mengenal batas wilayah, agama, suku dan ras. Kehadiran teknologi informasi dapat dimanfaatkan untuk mentransformasi sarana dan metode penginjilan yang sudah berjalan selama ini supaya semakin efektif. ${ }^{50}$ Perkembangan teknologi membuat internet menjadi salah satu cara yang paling efektif untuk memberitakan kebenaran Injil. ${ }^{51}$

Dengan adanya sistem komputerisasi dan telekomunikasi sejagat, maka setiap informasi dapat disampaikan oleh siapa saja dan kapan saja dan di mana saja dan diterima pada saat itu juga (real time). Media internet telah menjadi sarana utama manusia untuk melakukan apapun dan di mana pun. Setiap orang seakan-akan tersedot ke dalamnya. Dengan pemanfaatan media internet penyampaian Amanat Agung Tuhan Yesus akan dapat dilaksanakan secara efektif. ${ }^{52}$ Orang percaya bukan hanya dapat memanfaatkan internet sebagai sarana pelayanan dan pemberitaan Injil yang efektif melainkan juga dapat menemukan segala macam informasi dan sumber-sumber yang dibutuhkan untuk mendukung pelayanan penginjilan di internet. ${ }^{53}$ Selain itu, efektifitas pelaksanaan misi melalui media sosial juga didukung oleh kerjasama yang baik di antara gereja-gereja Tuhan dan dukungan doa dari seluruh umat percaya. Gereja perlu mendapatkan tenaga yang baik yang mempunyai konsep teologi misi yang benar karena Tuhan bekerja melalui manusia. ${ }^{54}$

Sekalipun media sosial menjadi sarana yang cukup efektif bagi pelaksanaan misi gereja pada masa kini, tidak dipungkiri ada pula kendala-kendala yang muncul dalam prakteknya. Seperti adanya serangan terhadap firman Tuhan yang diartikan tidak sesuai

\footnotetext{
${ }^{49}$ Laila Hayati, "Konsep Diri Anak-Anak Pengguna Aktif Media Sosial," Society, 2018, https://doi.org/10.33019/society.v6i2.65.

${ }^{50}$ Pasasa, "Pemanfaatan Media Internet Sebagai Media Pemberitaan Injil."

${ }^{51}$ Pasasa.

52 Pasasa.

53 Pasasa.

${ }^{54}$ Albert Konaniah, "Sekolah Teologi Dan Gerakan Penginjilan," Veritas : Jurnal Teologi Dan Pelayanan, 2018, https://doi.org/10.36421/veritas.v3i2.94.
} 
makna konteks dan teks dapat membingungkan orang percaya. Terlebih juga bagi orang yang keluar imannya dari kekristenan mempublikasikan kajian yang menyerang iman lewat media sosial juga dapat menjadi preseden buruk bila para creator tidak memberikan apologetikannya. Hal itu menjadi satu kendala tersendiri ketika orang yang belum percaya akhirnya memandang Kekristenan sebagai suatu agama yang membingungkan. Oleh karena itu pengunggah harus memiliki pemahaman misi yang benar secara alkitabiah. Selain itu, ketika ada ujaran-ujaran kebencian yang disampaikan dalam komentar sebuah unggahan dapat memicu rasa marah karena merasa Kekristenan atau Tuhan Yesusnya dihina. Hal itu membutuhkan kebijakan dan kedewasaan dari orang percaya sebagai pengunggah content misi agar tidak menimbulkan pertikaian yang ujungnya justru membuat orang semakin jauh dari Injil Kristus.

Kendala yang lain adalah mengenai tindak lanjut. Bagaimana dan siapa yang akan menindaklanjuti orang yang percaya sebagai hasil dari penginjilan melalui media sosial juga harus diperhatikan. Seperti yang disarankan Stevanus, untuk langkah follow up, bisa bekerjasama dengan gereja-gereja terdekat sebagai mitra misinya sehingga petobat baru tersebut dapat dimentoring dan digembalakan dengan dengan baik. ${ }^{55}$ Dan dapat dimotivasi untuk melakukan tugas-tugas pelayan dengan baik. ${ }^{56}$

\section{KESIMPULAN}

Dari apa yang telah diuraikan di atas, dapat ditarik kesimpulan bahwa misi Amanat Agung untuk memberikan Injil harus tetap dilakukan oleh gereja di mana pun dan kapan pun. Dan salah satu media untuk merealisasikannya adalah melalui media sosial. Media sosial di masa pandemi ini memiliki peran yang sangat signifikan dan efektif bagi Gereja dalam melaksanakan misi Allah. Injil dapat diberitakan tanpa batasan ruang dan waktu, juga tidak dibatasi oleh batas-batas negara dengan segala birokrasinya. Namun demikian, gereja tidak boleh mengabaikan pengajaran dan pelatihan kepada setiap anggota jemaat tentang pentingnya pemahaman misi yang alkitabiah serta materi misi yang dapat diunggah dalam

\footnotetext{
${ }^{55}$ Kalis Stevanus, Lihatlah Sang Juruselamat Dunia (Yogyakarta: Diandra Kreatif, 2018), 46.

${ }^{56}$ Ahmad Tabrani, "PENGARUH KEPEMIMPINAN DAN MENTORING TERHADAP MOTIVASI DALAM MELAYANI," EDULEAD: Journal of Christian Education and Leadership 1, no. 1 (2020): 77-91, https://doi.org/https://doi.org/10.47530/edulead.v1i1.23.
} 
HARVESTER: Jurnal Teologi dan Kepemimpinan Kristen, Vol 5, No 2, (Desember 2020)

content media sosial mereka. Diakui ada kendala-kendala yang muncul dalam pelaksanaan misi melalui media sosial, namun hal itu tidaklah menyurutkan semangat bermisi, sebaliknya pentingnya berjejaring dengan gereja-gereja sebagai mitra misinya. Untuk menjangkau seluruh lapisan umur, lapisan pendidikan, lapisan pekerjaan yang saat ini menggunakan daring dalam segala aktivitas, untuk mengurangi tertularnya covid-19.

\section{REFERENSI}

Abrahamsz, Stefany John Risna, and Petronella Tuhumury. "Model Penginjilan Dalam Yohanes 4:4-42 Dan Implementasinya Pada Masa Kini.” Jurnal Jaffray 10, no. 2 (2012): 104-39. https://doi.org/10.25278/jj71.v10i2.55.

Anwar, Fahmi. "Perubahan Dan Permasalahan Media Sosial." Jurnal Muara Ilmu Sosial, Humaniora, Dan Seni, 2017. https://doi.org/10.24912/jmishumsen.v1i1.343.

Ardha, Berliani. "Social Media Sebagai Media Kampanye Partai Politik 2014 Di Indonesia." Visi Komunikasi, 2014.

Arifianto, Yonatan Alex, and Asih sumiwi Rachmani. "Peran Roh Kudus Dalam Menuntun Orang Percaya Kepada Seluruh Kebenaran Berdasarkan Yohanes 16 : 13.” Jurnal Diegesis 3, no. 1 (2020): 1-12.

Arifianto, Yonatan Alex, Reni Triposa, and Paulus Karaeng Lembongan. "Bible Study of Mission and Discipleship in the Great Commission and Its Implications for Today's Christian Life.” Diegesis: Jurnal Teologi 5, no. 2 (2020): 25-42.

Baharudin, Iksan, Chairul, and Muhammad Abdi, Nur. “Ancaman Krisis Ekonomi Global Dari Dampak Penyebaran Virus Corona (Covid-19).” AkMen Jurnal Ilmiah, 2020.

Bosch, David J. Tranformasi Misi Kristen. Jakarta: BPK Gunung Mulia, 1998.

Cahyono, Anang Sugeng. "Pengaruh Media Sosial Terhadap Perubahan Sosial Masyarakat Di Indonesia." Jurnal Publiciana, 2016, 140-57.

Damarwanti, Seri. "Pandangan Rasul Paulus Tentang Jembatan Pengantar Injil. Kajian Misiologi Terhadap I Korintus 9:1-23.” SANCTUM DOMINE: JURNAL TEOLOGI, 2020. https://doi.org/10.46495/sdjt.v8i2.53.

Denney, Andrew S., and Richard Tewksbury. "How to Write a Literature Review." Journal of Criminal Justice Education 24, no. 2 (2013): 218-34. 
https://doi.org/10.1080/10511253.2012.730617.

Dever Mark. Sembilan Tanda Gereja Yang Sehat. Surabaya: Momentum, 2010.

Diana, Ruat. "Peran Komunikator Kristen Dalam Strategi Pekabaran Injil Di Era Revolusi Industri 4.0." Integritas: Jurnal Teologi, 2019.

Hannas, and Rinawaty. "Menerapkan Model Penginjilan Pada Masa Kini." Kurios 5, no. 2 (2019): 175-89.

Hartono, Handreas. "Mengaktualisasikan Amanat Agung Matius 28:19-20 Dalam Konteks Era Digital." Kurios 4, no. 2 (2018): 157-166.

Hayati, Laila. "Konsep Diri Anak-Anak Pengguna Aktif Media Sosial.” Society, 2018. https://doi.org/10.33019/society.v6i2.65.

Juliswara, Vibriza. "Mengembangkan Model Literasi Media Yang Berkebhinnekaan Dalam Menganalisis Informasi Berita Palsu (Hoax) Di Media Sosial.” Jurnal Pemikiran Sosiologi, 2017. https://doi.org/10.22146/jps.v4i2.28586.

Kalis Stevanus. “Karya Kristus Sebagai Dasar Penginjilan Di Dunia Non-Kristen.” Fidei: Jurnal Teologi Sistematika Dan Praktika Vol.3, no. No.1 (n.d.): 1-19.

—. Lihatlah Sang Juruselamat Dunia. Yogyakarta: Diandra Kreatif, 2018.

—. Panggilan Teragung: Pedoman Dan Metoda Praktis Untuk Memberitakan Kabar Baik Sampai Ke Ujung Bumi. Yogyakarta: Andi Offset, 2019.

Keriapy, Frets. "Pendidikan Kristiani Transformatif Berbasis Multikultural Dalam Konteks Indonesia." REGULA FIDEI: Jurnal Pendidikan Agama Kristen 5, no. 2 (2020): 8293.

Kirk, J. Andrew. Apa Itu Misiologi? Jakarta: BPK Gunung Mulia, 2015.

Konaniah, Albert. "Sekolah Teologi Dan Gerakan Penginjilan." Veritas : Jurnal Teologi Dan Pelayanan, 2018. https://doi.org/10.36421/veritas.v3i2.94.

Laia, Kejar Hidup. "Pertumbuhan Gereja Dan Penginjilan Di Kepulauan Nias." FIDEI: Jurnal Teologi Sistematika Dan Praktika, 2019. https://doi.org/10.34081/fidei.v2i2.46.

Lie, Heryanto David. "Penggenapan Progresif Misi Allah Dalam Kisah Para Rasul 1:8 Progressive Fulfillment of God 's Mission in Act 1 : 8." Jurnal Jaffray 15, no. 1 (2017).

Mendukung, Dalam, and Pembelajaran Pendidikan. "Penggunaan Media Sosial Di Kampus 
HARVESTER: Jurnal Teologi dan Kepemimpinan Kristen, Vol 5, No 2, (Desember 2020)

Dalam Mendukung Pembelajaran Pendidikan.” Jurnal Wacana XIV, no. 1 (2015): 4570.

Oci, Markus. "Implikasi Misiologi Dalam Pengembangan Kurikulum Agama Kristen Di Gereja Lokal.” FIDEI: Jurnal Teologi Sistematika Dan Praktika, 2019. https://doi.org/10.34081/fidei.v2i1.29.

Pasasa, Adrianus. “Pemanfaatan Media Internet Sebagai Media Pemberitaan Injil.” Jurnal Simpson 2, no. 1 (2015): 71-98.

Peters, George W. Teologi Pertumbuhan Gereja. Malang: Gandum Mas, 2013.

Putri, Wilga Secsio Ratsja, Nunung Nurwati, and Meilanny Budiarti S. "Pengaruh Media Sosial Terhadap Perilaku Remaja.” Prosiding Penelitian Dan Pengabdian Kepada Masyarakat 3, no. 1 (2016). https://doi.org/10.24198/jppm.v3i1.13625.

Rafi Saumi Rustian. “Apa Itu Sosial Media.” 01 Maret 2012, 2012.

Semiawan, Conny R. Metode Penelitian Kualitatif. Jakarta: Grasindo, 2010.

Stevanus, Kalis. Benarkah Injil Untuk Semua Orang. Yogyakarta: Diandra Kreatif, 2019.

__. "Mengimplementasikan Pelayanan Yesus Dalam Konteks Misi Masa Kini Menurut Injil Sinoptik.” FIDEI: Jurnal Teologi Sistematika Dan Praktika, 2018. https://doi.org/10.34081/fidei.v1i2.21.

Syafrida, Syafrida. "Bersama Melawan Virus Covid 19 Di Indonesia.” SALAM: Jurnal Sosial Dan Budaya Syar-I 7, no. 6 (2020). https://doi.org/10.15408/sjsbs.v7i6.15325.

Tabrani, Ahmad. "PENGARUH KEPEMIMPINAN DAN MENTORING TERHADAP MOTIVASI DALAM MELAYANI.” EDULEAD: Journal of Christian Education and Leadership 1, no. 1 (2020): 77-91. https://doi.org/https://doi.org/10.47530/edulead.v1i1.23.

Telaumbanua, Arozatulo. "E-Misi : Aplikasi Penginjilan Berbasis Teknologi.” In Prodising, 0:1-11, 2020.

Tomatala, Dr. Yakob. Penginjilan Masa Kini Jilid I. Malang: Gandum Mas, 2004. Utami, Anastasiaa Siwi Fatma, and Nur Baiti. "Pengaruh Media Sosial Terhadap Perilaku Cyberbullying Pada Kalangan Remaja.” Cakrawala - Jurnal Humaniora, 2018.

Wijaya, Elkana Chrisna. "Deskripsi Hamba Yang Menderita Menurut Yesaya 52:1353:12.” EPIGRAPHE: Jurnal Teologi Dan Pelayanan Kristiani, 2019. 
https://doi.org/10.33991/epigraphe.v2i2.38.

Woga, Edmund. Dasar-Dasar Misiologi. Yogyakarta: penerbit Kanisius, 2002. . Misi, Misiologi, Dan Evangelisasi Di Indonesia. Yogyakarta: penerbit Kanisius, 2009. 